In addition, wood as well as brick was found to be strongly active under the conditions employed. Metals exposed for some time outside the buildings showed a marked increase of activity over the metal which had been carefully cleaned.

McGill University, Montreal, March 12. E. RUTHERFORD.

\section{Mendel's Principles of Heredity in Mice.}

The points raised by Mr. Bateson in Nature of March ig cannot be discussed within the limits of a short letter; a full discussion will be published in an early number of Biometrika. In the meantime I would ask Mr. Bateson one question :-

He represents the mice used by $\mathrm{Mr}$. Darbishire as differing in two characters; one (pinkness of eye with white coat) he calls G; the other (pinkness of eye with some colour in the coat) he calls $\mathrm{G}^{\prime}$. The hybrids produced by crossing these mice he calls $\mathrm{GG}^{\prime}$; and by reference to the mysterious properties of "heterozygotes" any difficulties presented by their eye-colour are avoided. But when these hybrids are paired inter se, they are said to produce offspring of three kinds, in the proportions

$$
\mathrm{GG}+2 \mathrm{GG}^{\prime}+\mathrm{G}^{\prime} \mathrm{G}^{\prime} \text {. }
$$

Now the mice $G^{\prime} G^{\prime}$ are of the same constitution in respect of all the characters concerned as their pure-bred grand-parent $\mathrm{G}^{\prime}$. Mr. Darbishire has shown (Biometrika, vol. ii. part ii.) that they do not always resemble their grandparent, or either of their parents, in one of the characters (coat-colour) denoted by $\mathrm{G}^{\prime}$. They may show a new colour, "lilac," not present in any of their near ancestors. Six out of eighteen mice of this category, at present old enough for study, show lilac colour.

I would ask Mr. Bateson's explanation of this fact and of the coat-colour of the first hybrids $\mathrm{GG}^{\prime}$.

Oxford, March 24.

$$
\text { W. F. R. WELDON. }
$$

\section{Historical Note in regard to Determinants.}

IN the last-issued part of the American Journal of Mathematics, vol. xxv. pp. 97-106, there is a short paper by $\mathrm{Mr}$. E. D. Roe entitled " Note on Symmetric Functions" which in my opinion should not pass unnoticed. It concerns two fundamental theorems regarding alternants which it appears Mr. Roe had previously dealt with in the American Mathematical Monthly, vol. vi. (1899) p. 25, and had been there attributed by him to Prof. Gordan. In a footnote he now says :-

"Prof. Metzler has kindly called the writer's attention to the reference to Muir ('Determinants,' p. 176, § 129), from which it appears that Muir has the priority of publication, as far, at least, as theorem $i$. is concerned. It may, however, be added that in a recent letter Prof. Gordan states that he has used the two theorems for thirty years."

From this it might possibly be inferred that my publication of the said theorem twenty years ago, and Gordan's alleged private use of it thirty years ago, are matters of moment in connection with its history. This would be a fatal error, as the theorem has been in print for at least seventy-eight years, having been exhaustively dealt with by Schweins in his " Theorie der Differenzen und Differentiale, . . " published at Heidelberg in $1825 .^{1}$

The part of my connection with it which gives me most satisfaction is not the fact that I discovered it for myself but that I discovered an earlier and neglected discoverer of it, Schweins, and have since tried my best to do justice to his merits. His treatise had been absolutely lost sight of, even in Germany, until the appearance of my paper, "An Overlooked Discoverer in the Theory of Determinants," which was published in the Philosophical Magazine for November, 1884. In this paper was given a brief account of that portion of his work which concerned general determinants, and at the same time it was indicated that this was but a small fraction of the whole contents, several special determinants being equally familiar to him. 'In 1888 the subject was returned to, and entered into more fully in the Proceedings Roy. Soc. Edinburgh, vol. xv. pp. 526-542,

$1 V$. the second Abtheilung (pp. 369-398) and the second chapter of it in particular.

NO. I 744, VOL. 67$]$ the account there given being afterwards republished in the first volume of my " History of Determinants," pp. 157173. At a later date Schweins's chapter on alternants, extending to about thirty pages, was dealt with in a similar manner, the account appearing in a paper in the Proc. Roy. Soc. Edinburgh, vol. xxiii. pp. 93-132. On pp. 98ro3 of this the theorem will be found, accompanied by considerable detail. To the present day, nevertheless, Schwein has not received his due from any of his own countrymen.

Speaking generally, I would urge that the greatest possible caution should be exercised by everyone who finds it necessary to attach to a theorem the name of an author, not merely when the theorem concerns alternants, but when it belongs to any part of the general subject of determinants. As a second example, let us take a case where the mathematician who is unfairly dealt with is not German but English. No fact ought to be better known than that the first discoverer of continuants was Sylvester, his paper containing the discovery having been published in the Philosophical Magazine for June, 1853 . In the early part of 1875, however, S. Günther published a text-book which assigned the credit to the Danish mathematician, C. Ramus, and notwithstanding the fact that an effort was made in the Philosophical Magazine for February, 1877 (vol. iii. pp. 137-138), and still more pointedly in the American Journal of Mathematics for 1878 (vol. i. p. 344) to rectify the error, it has lingered on in Germany and the Continent of Europe to the present day. The details of the story are instructive. Günther's statement was :-

"Die Möglichkeit einer solchen Darstellung scheint zuerst von Ramus (Kjöbenhavn, Vid. Selsk. Overs. I855, pp. Io6-I I9) bemerkt worden zu sein : auch Spottiswoode (Crelle's Journ., 1i. p. 374) und Heine (Crelle's Journ., lvi. p. 97) wurden im Verlaufe anderweitiger Untersuchungen auf dieselbe geführt."

This was republished in 1877 without alteration. In opposition to it the following are the facts :-

(I) As above stated, Sylvester's discovery was published in June, 1853 .

(2) Spottiswoode, writing in August of the same year, and having just become familiar with Sylvester's discovery, reproduced the substance of the latter's remarks in the second edition of his " Elementary Theorems Relating to Determinants," which appeared in Crelle's Journal in 1856 .

(3) In September, 1853, Sylvester returned to the subject (v. Phil. Mag. [4] vi. pp. 297-299).

(4) In August, 1854, a result of Sylvester's on the subject appeared in the Nouv. Annales de Math., xiii. p. 305, under the significant title " Théorème sur les Déterminants de M. Sylvester."

(5) In 1855 , as Günther states, Ramus made his communication.

These five assertions have always been easily verifiable; and since the claim made publicly in 1877 and 1878 , ought to have been verified by any writer who had to refer to the subject. Strange to say, this has never been done, the most recent text-book, Pascal's, having only got as far as the following sentence indicates:-

"I primi che si sono occupati dell' argomento sono stati Ramus, Sylvester, Spottiswoode, Heine, Thiele, e Günther.'

If we turn for aid on such matters to the Encyklopädie der math. Wissensch., which is now in course of publication, and aims at being a standard work of reference, there is nought for us but disappointment. In connection with alternants, therein called "Vandermonde'sche" or "Potenzdeterminanten," the name of Schweins is not mentioned, and as for the early history of continuants, we find the old confusion worse confounded. Ramus's paper, it is true, does not appear, but unfortunately we are referred to one of still later date $\left(185^{8}\right)$, by Painvin, and to a note which is attributed to Sylvester, but which Sylvester never wrote. The name "continuant," too, is wrongly attributed, and when in connection with the application to continued fractions Sylvester's name is again mentioned, the first date attached thereto is 1859 ! This may be a misprint for 1853 , but if so there is a further error in the specification of the page. Heine's name is still to the fore; unluckily, however, it is not attached to the right paper. Something of Günther's is referred to, but the title is left out.

Cape Town, S.A., February $28 . \quad$ Tromas Muir. 